\title{
Quality of life of chronic renal patients undergoing hemodialysis
}

\author{
Qualidade de vida de pessoas com doença renal crônica em hemodiálise
}

Christielle Lidianne Alencar Marinho ${ }^{1}$, Jeany Freire de Oliveira ${ }^{1}$, Jéssica Eidler da Silva Borges ${ }^{1}$, Rudval Souza da Silva $^{1}$, Flávia Emília Cavalcante Valença Fernandes ${ }^{2}$

Objective: to analyze the quality of life of people with chronic kidney disease. Methods: cross-sectional, descriptive study with people undergoing hemodialysis. Data collection was performed with 105 participants. The Kidney Disease and Quality-of-Life Short-Form was used. Data were analyzed using mean, median and standard deviation. Results: the sample was predominantly male, older than 60 years and did not work. Work Status and Physical Function were the most affected quality of life dimensions, with averages of 14.76 and 43.1, respectively. The Cognitive Function and the Sexual Function presented the best results, with averages of 86.41 and 86.56. Conclusion: chronic kidney disease and hemodialysis treatment interfere with the individuals' quality of life, bringing greater losses in the work status and physical function, and better repercussion in the domains pain, social function, cognitive function and sexual function.

Descriptors: Nursing Care; Renal Insufficiency, Chronic; Quality of Life.

Objetivo: analisar a qualidade de vida de pessoas com doença renal crônica. Métodos: estudo transversal, descritivo com pessoas em hemodiálise. A coleta de dados foi realizada com 105 participantes e utilizou-se o instrumento Kidney Disease and Quality-of-Life Short-Form. Os dados foram analisados utilizando-se média, mediana e desvio padrão. Resultados: a amostra foi composta predominantemente pelo sexo masculino, idade acima de 60 anos e que não exercem atividade laboral. Situação de trabalho e Função Física foram as dimensões de qualidade de vida mais afetadas, com médias de 14,76 e 43,1, respectivamente. A Função Cognitiva e Função Sexual apresentaram melhores resultados, com média 86,41 e 86,56. Conclusão: a doença renal crônica e o tratamento hemodialítico interferem na qualidade de vida dos indivíduos, com maiores prejuízos nas dimensões de situação de trabalho e função física e melhor repercussão nos domínios dor, função social, função cognitiva e função sexual.

Descritores: Cuidados de Enfermagem; Insuficiência Renal Crônica; Qualidade de Vida.

\footnotetext{
${ }^{1}$ Universidade do Estado da Bahia. Senhor do Bonfim, BA, Brazil.

${ }^{2}$ Universidade de Pernambuco. Petrolina, PE, Brazil. 


\section{Introduction}

Chronic Kidney Disease is characterized by a progressive and irreversible decrease of renal function, as a multiple-cause and multifactorial result of structural and functional alterations of the kidneys. It is a prolonged, insidious and asymptomatic disease in the early stages ${ }^{(1)}$. Due to an increase in incidence and prevalence rates in recent years, it has been considered a public health problem and has generated high treatment $\operatorname{costs}^{(2)}$.

According to the Brazilian Society of Nephrology, the total estimated number of patients in the country, according to data from July 2014, was 112,004. This represents an increase of 20,000 patients in the last four years, with an average annual increase of $5.0 \%{ }^{(3)}$.

Once the medical diagnosis of chronic kidney disease has been established, one of the treatment options is hemodialysis, which promotes blood filtration through a capillary by removing the products from metabolic degradation and excess liquids ${ }^{(4)}$.

Hemodialysis is a necessary therapy for maintaining the life of the kidney disease patient and leads to a series of changes in the life of these individuals, such as the time spent on treatment, affecting their quality of life. The World Health Organization defines quality of life as the individual's perception of their own life from aspects that involve culture and the value system in which the person is inserted and relate them to their goals, expectations, standards and concerns $^{(5)}$.

Quality of life can be measured either through generic instruments, which can be applied to any specific population or instruments. The Kidney Disease and Quality-of-Life Short-Form (KDQOL-SFTM) instrument was developed for chronic renal patients undergoing renal replacement therapy, which has already been validated in Brazil(6).

Hemodialysis prolongs life, but does not fully control the changes in the natural course of the disea- se, producing inconstant results and limitations in the daily life, whose consequences compromise physical and psychological aspects, generating repercussions of personal, family and social order ${ }^{(7-8)}$.

Because it is a disease that causes a series of changes, restrictions and compromises daily activities, in addition to social interaction, it becomes necessary to know and evaluate its impact on the quality of life. Thus, this analysis will enable the nurse to establish therapeutic interventions based on knowledge, since knowledge can subsidize actions adopted by the nursing team, establishing a link and support to the patient and the family based on a comprehensive, humanized nursing care, allowing better adaptation to treatment and changes in lifestyle.

Thus, this study aims to analyze the quality of life of people with chronic kidney disease.

\section{Methods}

This is a cross-sectional study, carried out in November and December of 2015, in a hemodialysis clinic in a city that is part of the Identity Territory of Piemonte Norte do Itapicuru, in the interior of Bahia, Brazil. The said service offers both hemodialysis and peritoneal dialysis, and had, at the study moment, 198 patients undergoing hemodialysis, in addition to patients on peritoneal dialysis.

The following inclusion criteria were adopted: having a diagnosis of chronic kidney disease; undergoing the treatment three times a week; and having at least three months of treatment. The exclusion criteria were: age less than 18 years; patients with mental disability, confirmed in medical records; and inability to communicate or difficulty in answering the questionnaire. The sample was calculated using the population of 198 individuals, margin of error of $5.0 \%$, confidence level of $95.0 \%$ and population distribution of $80.0 \%$, according to the data provided by the institution in a study carried out previously. From the calculation, a sample of 110 patients was defined, 
which were selected using the random simple method through a random lottery conducted on the random. org website. Five patients refused to participate, totaling 105 participants.

The questionnaires were applied in the hemodialysis room, with an average duration of 15 minutes, and the participants were accommodated and in use of the respective machines.

Regarding sociodemographic and clinical data, a questionnaire containing the following variables was used: gender, age, marital status, years of study, income, work, treatment time, presence of hypertension and/or diabetes.

To evaluate the quality of life, the instrument Kidney Disease and Quality of Life Short Form (KDQOL-SF $^{\text {TM }} 1.3$ ) was used ${ }^{(7)}$. This instrument has been translated, validated and culturally adapted to the Brazilian population. Intra- and inter-observer reliability was statistically significant, and high values for Cronbach's $\alpha$ coefficient were obtained, varying from 0.65 to 0.99 across all dimensions of the instrument ${ }^{(6)}$.

The Kidney Disease and Quality of Life Short Form is an instrument that includes, as a generic measure of evaluation of the overall health status of the individual, the Short-Form Health Survey (SF-36), consisting of eight domains (physical functioning, physical function, social function, emotional well-being, pain, energy/fatigue and overall health status) and a scale with eleven specific dimensions for people with chronic kidney disease undergoing dialysis (symptoms/physical problems, effects of kidney disease, burden of kidney disease, work status, cognitive function, quality of social interaction, sexual function, sleep, social support, dialysis staff encouragement and patient satisfaction).

Each answer was coded and received a score, which was later transformed into a scale from 0 to 100 , where the value 0 reflects a worse quality of life and the value 100 reflects a better quality of life.

Data Analysis and Statistical Software version
12.0 was used to analyze the data. Central tendency (average) and dispersion (standard deviation) measures were calculated. $95.0 \%$ confidence intervals were calculated for the mean $(95.0 \% \mathrm{CI}=\mu \pm 1.96 \mathrm{SE})$, where $\mu$ is the sample mean, SE - standard error, for each domain and for the proportion assuming the binomial distribution.

The study complied with the formal requirements contained in the national and international regulatory standards for research involving human beings.

\section{Results}

Table 1 shows sociodemographic characteristics and clinical aspects. Of the total number of participants, $57.1 \%$ were male; $30.5 \%$ were over 60 years of age; $46.7 \%$ were married and $88.6 \%$ did not work. Most participants received up to a minimum wage (83.8\%) and regarding schooling, $63.8 \%$ had incomplete elementary school.

Regarding the clinical aspects, among the comorbidities, systemic arterial hypertension was the most prevalent $(78.1 \%)$, followed by diabetes mellitus $(27.8 \%)$. Hemodialysis time varied between three months and five years of treatment, with the latter presenting a higher percentage, $36.2 \%$ (Table 1 ).

Table 2 compares the current overall health assessment and that of one year ago. It was noticed that $42.9 \%$ of the participants classified the current overall health status as fair, and compared $40.9 \%$ a year ago, $40.9 \%$ answered it is excellent.

Table 3 shows the mean, standard deviation and confidence interval of both the general and specific domains covered by the instrument. The most affected dimensions are related to work status and physical function, with means of 14.76 and 43.1, respectively. The domains with the highest averages were: Sexual Function (86.56), Cognitive Function (86.41), Social Function (75.36) and Pain (75.62). 
Table 1 - Sociodemographic characteristics and clinical aspects of chronic renal patients undergoing hemodialysis $(\mathrm{n}=105)$

\begin{tabular}{|c|c|c|}
\hline Variable & n (\%) & CI95\%* \\
\hline \multicolumn{3}{|l|}{ Sex } \\
\hline Male & $60(57.1)$ & $47.5-66.8$ \\
\hline Female & $45(42.9)$ & $33.2-52.5$ \\
\hline \multicolumn{3}{|l|}{ Age group } \\
\hline $18-28$ & $11(10.5)$ & $4.5-16.4$ \\
\hline $29-39$ & $17(16.2)$ & $9.0-23.4$ \\
\hline $40-49$ & 27 (25.7) & $17.2-34.2$ \\
\hline $50-59$ & $18(17.1)$ & $9.8-24.5$ \\
\hline$>59$ & $32(30.5)$ & $21.5-39.4$ \\
\hline \multicolumn{3}{|l|}{ Marital status } \\
\hline Married & $49(46.7)$ & $37.0-56.4$ \\
\hline Single & $40(38.1)$ & $28.7-47.5$ \\
\hline Widowed & $4(3.8)$ & 0.1-7.5 \\
\hline Divorced & $12(11.4)$ & $5.2-17.6$ \\
\hline \multicolumn{3}{|l|}{ Years of study } \\
\hline 0 to 1 & $17(16.2)$ & $9.0-23.4$ \\
\hline 2 to 8 & 67 (63.8) & $54.5-73.2$ \\
\hline 9 to 15 & $21(20.0)$ & $12.2-27.8$ \\
\hline \multicolumn{3}{|l|}{ Income } \\
\hline Up to 1 & $88(83.8)$ & $76.6-91.0$ \\
\hline 2 to 4 & $14(13.3)$ & $6.7-19.9$ \\
\hline$\geq 5$ & $1(1.0)$ & $-0.9-2.8$ \\
\hline No income & $2(1.9)$ & $-0.8-4.6$ \\
\hline \multicolumn{3}{|l|}{ Work } \\
\hline No & $93(88.6)$ & $82.4-94.8$ \\
\hline Yes & $12(11.4)$ & $5.2-17.6$ \\
\hline \multicolumn{3}{|c|}{ Time undergoing hemodialysis } \\
\hline 3 to 6 months & $1(1.0)$ & $-0.9-2.8$ \\
\hline 7 to 11 months & $6(5.7)$ & $1.2-10.2$ \\
\hline 1 to 5 years & $60(57.1)$ & $47.5-66.8$ \\
\hline$>5$ years & $38(36.2)$ & $26.8-45.5$ \\
\hline \multicolumn{3}{|l|}{ Diabetic } \\
\hline Yes & $29(27.6)$ & $18.9-36.3$ \\
\hline No & $76(72.4)$ & 63.7-81.1 \\
\hline \multicolumn{3}{|l|}{ Hypertensive } \\
\hline Yes & $82(78.1)$ & $70.1-86.1$ \\
\hline No & 23 (21.9) & $13.9-29.9$ \\
\hline
\end{tabular}

Table 2 - Overall Health Status of chronic renal patients undergoing hemodialysis $(n=105)$

\begin{tabular}{|c|c|c|}
\hline \multirow{2}{*}{ Overall health assessment } & Current & Compared to a year ago \\
\hline & n (\%) & n (\%) \\
\hline Excellent & $5(4.8)$ & $43(40.9)$ \\
\hline Very Good & $2(1.9)$ & $21(20.0)$ \\
\hline Good & $40(38.1)$ & $25(23.8)$ \\
\hline Fair & $45(42.9)$ & $7(6.7)$ \\
\hline Poor & $13(12.4)$ & $9(8.6)$ \\
\hline
\end{tabular}

Table 3 - KDQOL-SF domains of chronic renal patients undergoing hemodialysis $(\mathrm{n}=105)$

\begin{tabular}{lccc}
\hline Domain & Mean & $\begin{array}{c}\text { Standard } \\
\text { deviation }\end{array}$ & CI* \\
\hline General & & & \\
Physical functioning & 59 & 27.7 & $53.6-64.4$ \\
Função Física & 43.1 & 39.1 & $35.5-50.7$ \\
Pain & 75.6 & 31.1 & $69.6-81.6$ \\
Overall health status & 53.9 & 18.1 & $50.4-57.4$ \\
Emotional well-being & 69.1 & 17.6 & $65.7-72.5$ \\
Emotional function & 63.5 & 45.2 & $54.7-72.2$ \\
Social function & 75.4 & 24.1 & $70.7-80.0$ \\
Energy/Fatigue & 67.1 & 18.5 & $63.5-70.7$ \\
Specific & & & \\
List of symptoms / problems & 82.9 & 12.0 & $80.6-85.2$ \\
Effects of kidney disease & 76.1 & 18.5 & $72.6-79.7$ \\
Burden of kidney disease & 48.4 & 28.2 & $42.9-53.8$ \\
Work status & 14.8 & 28.5 & $9.2-20.3$ \\
Cognitive function & 86.4 & 18.0 & $82.9-89.9$ \\
Quality of social interaction & 80.5 & 16.9 & $77.2-83.8$ \\
Sexual function & 86.6 & 21.9 & $80.5-92.6$ \\
Sleep & 69.0 & 24.0 & $64.3-73.6$ \\
Social support & 77.6 & 32.4 & $71.3-83.9$ \\
Dialysis Staff Encouragement & 78.1 & 22.9 & $73.7-82.5$ \\
*95\% CI - 95\% Confidence Interval for the average domains & $61.1-69.4$ \\
\hline
\end{tabular}

\section{Discussion}

Regarding limitations deriving from the design of this study (cross-sectional), it is worth mentioning its descriptive character, since no associations were made between sociodemographic variables and the quality of life instrument. This fact made it difficult to compare this study with other studies. Thus, in order to make this approach more effective, further studies should be carried out in an attempt to evidence these relationships, in order to intervene more effectively in factors that have a direct relationship with the quality of life of people with chronic kidney disease. 
The analysis of the sample enabled verifying a greater number of elderly patients undergoing hemodialysis treatment. This reality may be related to the advancement of life expectancy, as well as the greater vulnerability of this population to chronic noncommunicable diseases such as hypertension and diabetes mellitus, comorbidities that favor the development of chronic kidney disease $\mathrm{e}^{(9)}$. In the case of these disorders, arterial hypertension was the most frequent comorbidity among the study participants, a fact corroborated by other Brazilian studies ${ }^{(4,10-11)}$.

In relation to the years of study, most participants had incomplete elementary school, which indicates low schooling. In a similar study, it was described that people with lower educational level may feel more strongly the impact of chronic kidney disease on their activities, or may not adhere to treatment or perform it inappropriately ${ }^{(10)}$. In contrast, another study ${ }^{(11)}$ identified that schooling does not influence the evolution of chronic kidney disease.

Still in this context, low schooling can interfere with adherence and adequate treatment and quality of life, since it compromises access to health education and represents difficulties in understanding the guidelines carried out by professionals. Nurses should be aware of the way in which they communicate with patients and their families, taking into account their individuality and ability to understand information ${ }^{(12-13)}$.

Most participants have income up to a minimum wage, derived from social grants provided by the government for not being able to develop activities due to physical limitations and to the time spent on treatment. Some studies associate low income with low schooling, stating that these two characteristics result in unfavorable life conditions, higher prevalence of chronic kidney disease and other chronic diseases, with consequent increase in morbidity and mortality ${ }^{(14)}$.

In the case of marital status, there was a prevalence of married people, which allows us inferring that having a partner helps minimizing the impact of chronic kidney disease and adapting to changes cause by the disease. Marital relationship can also positively influence the quality of life ${ }^{(9)}$, since it is of fundamental importance for the satisfaction of emotional needs and the psychosocial well-being of individuals ${ }^{(15-16)}$.

Regarding treatment time, there may be a relationship between relatively high averages of quality of life and longer treatment time. This demonstrates the prolongation of the life of the person with chronic kidney disease and, over time, changes appear as to their perception about quality of life, bringing greater adaptation to their health status, reflecting in the improvement of quality of life in some dimensions ${ }^{(16-17)}$.

Treatment time has contributed to improved quality of life when individuals compare their current health status with that of the previous year and the results show an improvement of this perception, a fact corroborated by other similar studies ${ }^{(9-10)}$. Although hemodialysis provokes physical and social limitations, it also allows, over time, the reduction of complications and fear of death, which can serve as motivation for coping with the disease and adaptation to the restrictions, contributing to improved perception of health status ${ }^{(9)}$.

For those people who find a positive meaning for the treatment, the disease happens to have a lighter weight in the life of the individual and the patient manages to permanently seek a positive re-signification of their experiences, with improvement of the symptoms and consequent improvement of quality of life.

The nurse plays an essential role in the process of acceptance of the disease by the patient through provision of bond and continuous support. The educational process aimed at preparing the patient to develop life skills through self-care is also extremely necessary and it is up to the nurse to work with the multidisciplinary team in this aspect as well(16).

As regards the Kidney Disease and Quality of Life Short Form domains, the domain that obtained 
the highest score was Sexual Function (86.56). This domain assesses whether patients have engaged in sexual activity in the past four weeks and the extent of problems to arousal and sexual satisfaction. Similar results have been found in other studies ${ }^{(4,18)}$. A cautious analysis must be carried out, considering the number of participants in the sample who reported having sex, since erectile dysfunction is a very prevalent condition in patients with chronic renal failure.

Sexual decline is inherent in the usual progression of chronic kidney disease due to hormonal, physical, neurological, and psychological changes. Because of this, individuals on hemodialysis are, for the most part, less sexually active than healthy people, and are often afflicted with erectile dysfunction in men, menstrual abnormalities in women and decreased libido and fertility in both sexes ${ }^{(16)}$.

The other domains with high scores were: Cognitive Function (86.41), Pain (75.62) and Social Function (75.36), similar findings to other studies using the same instrument ${ }^{(4,10-11,18-19)}$. Chronic renal patients constitute a population at risk for cognitive decline. So, although the Cognitive Function has one of the highest scores, it is necessary to incorporate a periodic evaluation of this function in the care of these patients so that it is possible to delay this decline ${ }^{(4)}$.

As for the lower level of quality of life, the lowest means were found in Work Situation (14.76) and Physical Function (43.1), also reported in the literature ${ }^{(4,10-11,18)}$. The "physical function" dimension is related to the presence of physical symptoms of the disease and hemodialysis, such as complaint of weakness, fatigue and malaise, as well as limitations related to type and amount of work or performance of other activities, which leads to a negative impact on the quality of life in this aspect ${ }^{(4,10)}$.

One of the most common changes that affect the renal patient at productive age is related to work, since it is difficult to reconcile treatment with a formal job. Most are unable to stay in the job market, needing to receive social grants from the government, which is often less than their income before illness. Financial problems end up shaking not only the sick person, but it has repercussions in the family and influences other aspects of life, such as eating habits, leisure, transportation, among others.

Faced with this perspective, it is up to the nurse to develop a quality communication that meets the experience and individuality of the person, being attentive to the scientific and technical development in relation to the illness, treatment and the nursing diagnoses, also developing the ability to appreciate and to deepen knowledge on the practices, customs, feelings and experiences intrinsic to each individual ${ }^{(14)}$.

Considering these aspects, the presence of an interpersonal relationship based on the link between professional and patient helps in the identification of needs, and positively interferes with the well-being and perceptions of the subject with the disease, thus enabling the nurse to perform a health education, guiding patient and about the disease and treatment, limitations, complications and possible problems ${ }^{(9)}$.

This study enables nurses to develop therapeutic interventions for the quality of life of patients undergoing hemodialysis. The nurse, who is aware of the most deficient aspects of the quality of life of this population, can direct their care in order to provide patient satisfaction and targeted assistance to their needs.

\section{Conclusion}

The results showed that chronic kidney disease and hemodialysis treatment interfere with the individuals' quality of life, with greater losses in the work situation and physical function, and a better repercussion in the domains of pain, social function, cognitive function and sexual function. 


\section{Collaborations}

Marinho CLA contributed to the project design, data collection, analysis and interpretation, article writing and approval of the final version to be published. Oliveira JF and Borges JES contributed to project design, data analysis and interpretation and article writing. Silva RS and Fernandes FECV contributed in the writing, critical review of the content and approval of the final version to be published.

\section{References}

1. Ministério da Saúde (BR). Diretrizes Clínicas para o Cuidado ao paciente com Doença Renal Crônica - DRC no Sistema Único de Saúde. Secretaria de Atenção à Saúde. Departamento de Atenção Especializada e Temática. Brasília: Ministério da Saúde; 2014.

2. Pinho NA, Silva GV, Pierin AMG. Prevalence and factors associated with chronic kidney disease among hospitalized patients in a university hospital in the city of São Paulo, SP, Brazil. J Bras Nefrol. 2015; 37(1):91-7.

3. Sesso RC, Lopes AA, Thomé FS, Lugon JR, Martins CT. Inquérito Brasileiro de Diálise Crônica 2014. J Bras Nefrol. 2016; 38(1):54-61.

4. Lopes JM, Fukushima RLM, Inouye K, Pavarini SCI, Orlandi, FS. Quality of life related to the health of chronic renal failure patients on dialysis. Acta Paul Enferm. 2014; 27(3):230-6.

5. Franco LC, Zatta LT, Vasconcelos P, Barbosa MA, Santos JRS, Rosa LFO. Evaluación de la calidad de vida de pacientes de insuficiencia renal crónica en diálisis renal. Enferm Global. 2011; 10(23):16571.

6. Duarte PS, Miyazaki MCOS, Ciconelli RM, Sesso R. Tradução e adaptação cultural do instrumento de avaliação de qualidade de vida para pacientes renais crônicos (KDQOL-SF TM). Rev Assoc Med Bras. 2003; 49(4):375-81.

7. Patat CL, Stumm EMF, Kirchner RM, Guido LA, Barbosa DA. Análisis de la calidad de vida de los usuarios de hemodiálisis. Enfer Global. 2012; 11(27):54-65.
8. Medeiros RC, Sousa MNAS, Nunes RMV, Costa TS, Moraes JC, Diniz MB. Health-related quality of life of individuals under hemodialysis. J Nurs UFPE on line [on line]. 2015; [cited 2016 Ago 09]; 9(Suppl. 9):1018-27. Available from: http://www.revista. ufpe.br/revistaenfermagem/index.php/revista/ article/view/5328/pdf_8968

9. Coitinho D, Benetti ERR, Ubessi LD, Barbosa DA, Kirchner RM, Guido LA, et al. Intercorrências em hemodiálise e avaliação da saúde de pacientes renais crônicos. Av Enferm. 2015; 33(3):362-71.

10. Cavalcante MCV, Lamy ZC, Filho FL, França AKTC, Santos AM, Thomaz EBAF, et al. Factors associated with the quality of life of adults subjected to hemodialysis in a city in northeast Brazil. J Bras Nefrol. 2013; 35(2):79-86.

11. Santos GD, Castilho MS, Viso BF, Carreira GF, Queiroz MIP, Mello TRC, et al. Qualidade de vida de pacientes em hemodiálise na cidade de Mogi das Cruzes. Diagn Tratamento. 2014; 19(1):3-9.

12. Andrade JMO, Rios LR, Teixeira LS, Vieira FS, Mendes DC, Vieira MA, et al. Influência de fatores socioeconômicos na qualidade de vida de idosos hipertensos. Ciênc Saúde Coletiva. 2014; 19(8):3497-504.

13. Oliveira AM, Soares E. A comunicação como importante ferramenta nas orientações em uma unidade de hemodiálise: um estudo reflexivo. Sau Transf Soc. 2014; 5(3):118-23.

14. Nunes MB, Santos EM, Leite MI, Costa AS, Guihem DB. Epidemiological profile of chronic kidney patients on dialysis program. J Nurs UFPE on line [on line]. 2013; [cited 2016 Jun 10]; 8(1):69-76. Available from: http://www.revista.ufpe.br/ revistaenfermagem/index.php/revista/article/ view/5398/pdf_4411

15. Santos RI, Costa ORS. Avaliação da resiliência em pacientes com insuficiência renal crônica submetidos à hemodiálise. Rev Ciênc Saúde. 2016; 6(1):5-13.

16. Fortes VLF, Bettinelli LA, Pomatti DM, Brock J, Dobner T. The chronic renal disease course: from early symptons to Discovery. Rev Rene. 2013; 14(3):531-40. 
17. Teixeira ÁLF, Ubessi LD, Benetti ERR, Kirchner RM, Barbosa DA, Stumm EMF. Events associated with the daily life of elderly under hemodialysis. Cienc Cuid Saúde. 2015; 14(3):1377-84.

18. Gonçalves FA, Dalosso IF, Borba JMC, Bucaneve J, Valerio NMP, Okamoto CT, et al. Quality of life in chronic renal patients on hemodialysis or peritoneal dialysis: a comparative study in a referral service of Curitiba - PR. J Bras Nefrol. 2015; 37(4):467-74.
19. Acuña CP, Hernández, GR, Goldenberg JS, Rodríguez IA. Relación entre calidad de vida y representación de enfermedad en personas con enfermedad renal crónica terminal en tratamiento con hemodiálises. Enferm Nefrol. 2015; 18(2):8996. 